\title{
THE MESA OF OYBIN (UPPER LUSATIA, GERMANY) AND ITS IMPORTANCE FOR GEOLOGY AND GEOTOURISM
}

\author{
Jiří BERÁNEK \\ VŠB - Technical University of Ostrava, Faculty of Mining and Geology, Department of \\ Geological Engineering, e-mail: jiri.beranek1@vsb.cz, 17, listopadu 2172/15, 708 oo Ostrava
}

\author{
Beáta KORANDOVÁ* \\ VŠB - Technical University of Ostrava, Faculty of Mining and Geology, \\ Department of Geological Engineering, e-mail: beata.korandova@vsb.cz

\section{Dana VRUBLOVÁ} \\ VŠB - Technical University of Ostrava, Faculty of Mining and Geology, \\ Department of Geological Engineering, e-mail: dana.vrublova@vsb.cz
}

\begin{abstract}
Citation: Beránek, J., Korandová, B., \& Vrublová D. (2019). THE MESA OF OYBIN (UPPER LUSATIA, GERMANY) AND ITS IMPORTANCE FOR GEOLOGY AND GEOTOURISM. GeoJournal of Tourism and Geosites, 25(2), 391-398. https://doi.org/10.30892/gtg.25210-368

Abstract: The aim of this article is to call attention to the most interesting place in the Zittau Mountains (Upper Lusatia, Germany), the mesa of Oybin. Besides ruins of the medieval Oybin castle and monastery, there are several examples of geological processes connected with the Upper Cretaceous sedimentation and later erosion in local quartz sandstones. The mesa itself provides an excellent witness of the deposition cycles, probable subaquatic landslides as well as various examples of later weathering. Selected features have been photographed, consulted with relevant literary sources and their probable origin discussed within the text. Photos of selected phenomena are included and explained in details. Visibly denoted and enlightened geological features could increase the tourist attractiveness of the mesa in terms of a complete description of this interesting mountain.
\end{abstract}

Key words: Zittau Mountains, Oybin mesa, Oybin castle and monastery, Upper Cretaceous sandstones, Lusatian fault, erosion, suffosion

\section{INTRODUCTION}

The aim of this article is describing several interesting geological features of the Oybin mesa in the Lužické (Lusatian) Mountains in order to explain these phenomenons to people interested in nature. This part of the Upper Lusatia represents a very interesting area with specific geology. The Upper Cretaceous sediments were penetrated by Tertiary igneous rocks. The main controlling structure - Lusatian fault - was in detail described by Fediuk et al., (1958) and later Chlupáč (1987) emphasized its importance for vertical

\footnotetext{
* Corresponding authors
} 
movements of peripheral blocks here. Wilmsen with Niebuhr (2014) reviewed the Saxon Upper Cretaceous and other authors (Wenger et al., 2017) summarized the knowledge regarding volcanism in this region, probably the oldest known manifestation of the asymmetric Eger graben (Cajz, 2004). Historical significance of this part of Lusatia was emphasized - for example - by Koláček (2014). Properties of local building stones are discussed by Michalski et al. (2002) and those who are interested in medieval architecture can find useful chapters regarding former construction methods in Šefců (2013).

The mesa of Oybin itself is situated in the Zittau Mountains about $7 \mathrm{~km} \mathrm{SSW}$ from the Saxon town of Zittau. This expressive sandstone massif lies near the northern slope of an elliptical depression (about $3 \mathrm{~km}^{2}$ ) created by the Goldbach stream and its small confluents. The area is drained via a short $\mathrm{V}$-shaped valley to NNE. This valley is then widely opened into the Zittau basin near the German - Polish frontier.

The mesa itself is the main attraction of Oybin, a small spa town connected with Zittau by a famous narrow gauge railway. On the top of the mesa, there is a large medieval castle with monastery (Figure 1), rebuilt during the late reign of Charles IV. The castle (together with the Fortress of Königstein) belongs among key touristic attractions in Saxony. However, the mesa of Oybin offers considerable examples of geological processes, both past and recent. In this article, we describe and explain several of them for tourists and nature friends to understand this location as a whole.

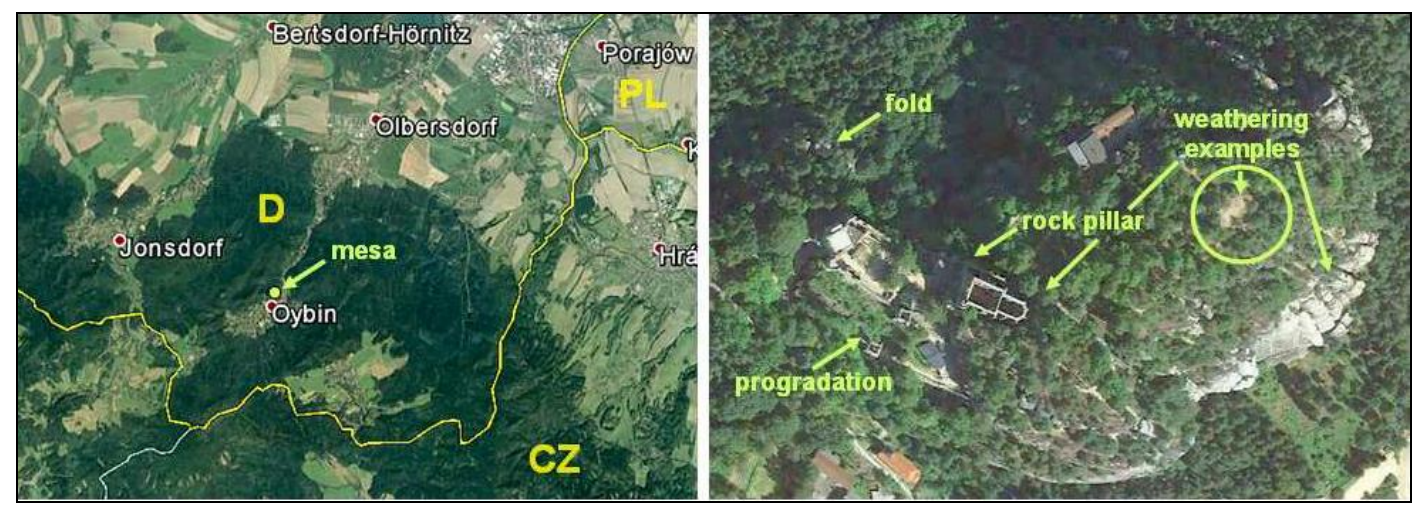

Figure 1. The mesa of Oybin with main geological attractions (Source: https://www.google.cz/maps/place/Oybin)

\section{A BRIEF OVERVIEW OF LOCAL GEOLOGY}

The Zittauer Gebirge is a deeply eroded block of Cenomanian - Turonian quartz sandstones and gravel conglomerates penetrated with Tertiary volcanic rocks (Figure 2) connected with the Eger graben very early development (Cajz, 2004, Wenger et al., 2017).

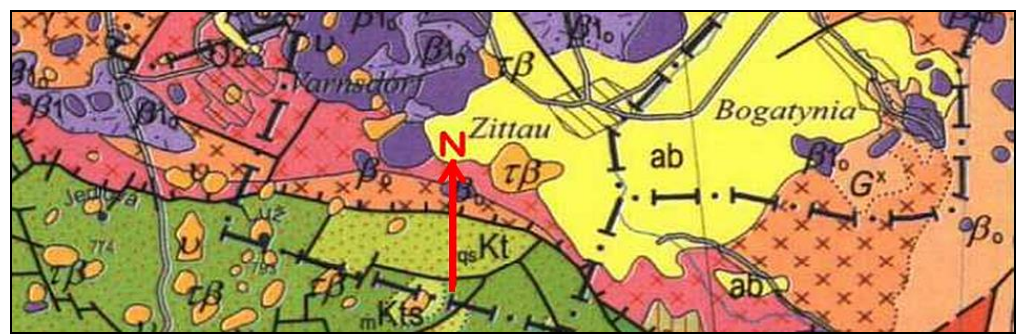

Figure 2. Geological map of the Zittau Mountains (Germany) with indicated profile (red)

(Source: Cháb et al., 2007) 
In the simplified geological map, particular symbols mean: $\boldsymbol{G}^{\boldsymbol{x}}$ are pre-Variscan metagranites, metagranodiorites and orthogneisses; $\mathbf{y}^{\boldsymbol{x}}$ pre-Variscan granites and granodiorites; $\mathbf{y}^{+}$Variscan intrusions; $\boldsymbol{f}$ phyllites (uncertain age); $\boldsymbol{B}$ Precambrian green schists; qsKt Lower-Upper Turonian (quartz sandstones); sKts Upper Turonian-Santonian (siltstones, fine sandstones, quartz sandstones; mKts Upper Turonian-Santonian, calcareous claystones and marls; $\boldsymbol{\beta}_{\mathbf{o}}$ olivinic igneous rocks; $\boldsymbol{\beta}_{\mathbf{o}}$ subaquatic effusions and intrusions (Eger graben); ${ }^{a} \boldsymbol{\beta} \mathbf{1}$ pyroclastic materials; $\boldsymbol{\tau} \boldsymbol{\beta}$ trachytes; $\boldsymbol{v}$ phonolites; ab Miocene (Aquitanian-Badenian) - sands, gravels, clay, inferior coal seams. The direct segment of frontier (bottom left, dash-dotted) represents $13.2 \mathrm{~km}$ here. The Mesa of Oybin is situated within the light green area, indicated with the symbol of $\mathbf{q s} \mathbf{K t}$. North is oriented upwards (red arrow). One full segment of dash-dotted line represents a distance about $1,5 \mathrm{~km}$. The whole block was uplifted along the Lusatian fault while the Zittau basin in the North dropped. These motions were most intensive between 1.3 Ma and $340 \mathrm{Ka}$ (Wenger et al., 2017). Today, altitudinal differences are in the order of hundreds meters. Moreover, such vertical ascends and descents (see the simplified geological profile - Figure 3) have still been going on and they are known as the Saxonian tectonics (Svoboda, 1983). The left part of Fig. 3 demonstrates the Middle Paleocene - Lower Eocene (62 - 50 Ma) phase; Lusatian block is uplifted and granitic alluvial fans drop down into the Labe zone. In the center, situation between the Upper Eocene and Lower Oligocene (34 - 29 Ma) is depicted - the relief between both blocks is leveled. The right part demonstrates the Lower Pleistocene conditions (after 1.3 Ma). Lusatian Mountains are upthrown (max. uplift $320 \mathrm{Ka}$ ) due to revived basin subsidence and sandstones are exposed to erosion. Green blocks represent the Cretaceous sediments of the Labe zone, Lusatian granites and their alluvial fans are red and brown, respectively. Tertiary volcanoes are indicated too (center, right).
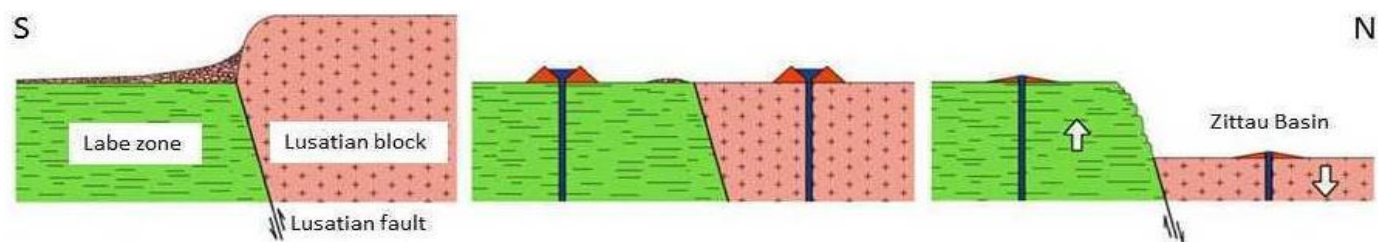

Figure 3. Geological profile across the Lusatian fault, the profile is drawn in Figure 2 (red arrow)

(Source: Adapted from Wenger, 2017)

During the Turonian, a shallow epikontinental sea penetrated from NW far into the Bohemian Massif along the zone of Labe (Elbe) lineament. There were three isolated sources of eroded materials - the Krušné hory (Erzgebirge) mountains area (then a flat elevation as the main source of sediments), the Lusatian Island and another flat land in the East (Wilmsen \& Niebuhr 2014). In the Lower Turonian, there was a shallow strait between the Lusatian Island and the Erzgebirge area. Sediments had a coastal character (i.e. conglomerates and coarse sandstones of the so called Oybin formation). The sea level would vary in cycles; rocks have the slant bedding and progradation pattern in the tidal zone. Materials were transported to NW and sediments - still finer - are typical for the Saxon Switzerland (Wilmsen \& Niebuhr, 2014). After a short but considerable phase of regression, the sea deepened again at the beginning of Middle Turonian. The Erzgebirge region lost its importance as the key area of denudation; the Western Sudetes Island assumed its role. A major part of siliciclastic rocks as well as fine grained fractions (marles) comes from this island (Wilmsen \& Niebuhr, 2014). Sandstones of the formation are roughly dated between $94-90$ Ma (Wilmsen \& Niebuhr, 2014). They still preserve their authentic horizontal position. This fact is very interesting in view of the fact that near the Lusatian fault strata are usually slanted or even overturned (Chlupáč, 2002). 


\section{METHODOLOGY}

Wide-angle photos of selected geological features were taken in order to describe them in details as well as to explain their origin. However, they could not be exactly measured because they are mostly inaccessible. Their size was thus estimated on the basis of measuring the distance (Stanley STHT1 laser meter) and comparison with known objects (stone blocks, portals, etc.). In the case of subaquatic fold described below, three probable scenarios of its origin were proposed and depicted. All features were carefully consulted with respective literary sources, in several cases scarce or less attainable. The resulting text could answer for a basic knowledge of these geological phenomena (in future, information leaflets with indicated locations might be printed or information plates installed for castle visitors to make of the local geology).

\section{GEOLOGICAL ATTRACTIONS OF THE MESA}

A very interesting geological phenomenon is situated in the northern part of mesa massif. Among adjacent (almost horizontal) sandstones there is a typical isoclinal fold better expressed, its remnant due to weathering (Figure 4). The fold axial plane is inclined towards the North by some 40 degrees. Such a fold is very unusual.

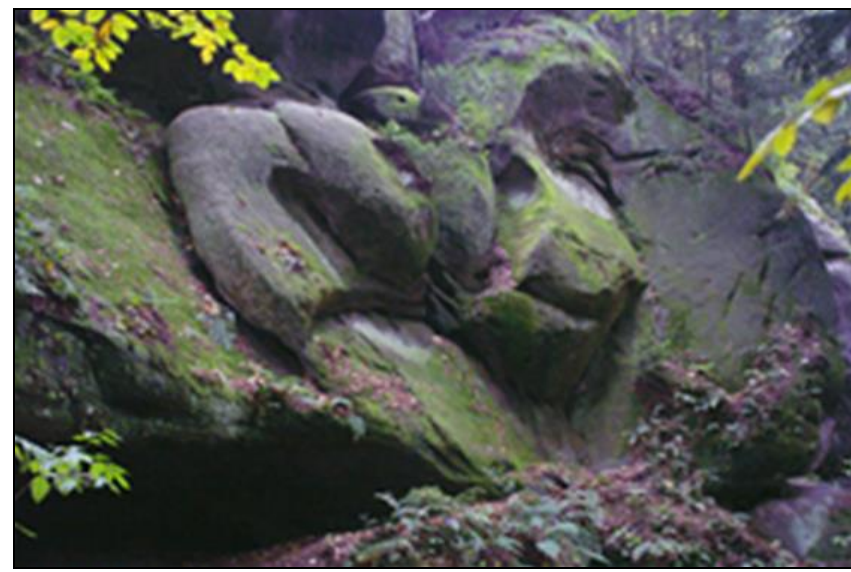

Figure 4. Remnants of underwater landslide folding in a later stage of lithification (diagenesis)

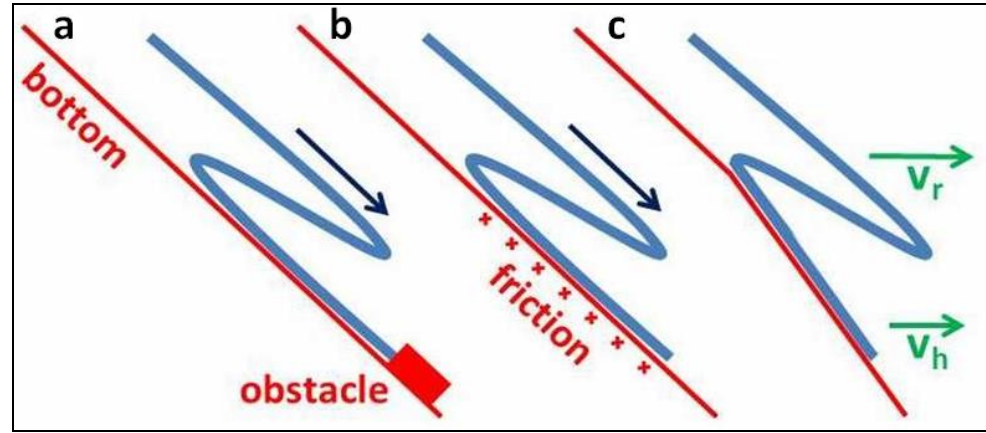

Figure 5 a, b, c. Three proposed scenarios of the fold origin

It is not very easy to explain its origin - however, the so called Saxon tectonics may be reliably rejected: the above mentioned Lusatian fault does not affect nearby rocks in any way. Some authors (Lewis, 1971; Ricketts, 2018) have described similar structures 
which could origin during the later phase of sedimentation. Rock layers are still plastic to avoid any brittle deformation but they already prove an adequate cohesion. This usually happens during the process of lithification (diagenesis) and the Oybin fold may thus be explained in the following way (Figure 5) - a moving layer of underwater landslide probably run into an obstacle. Its face stopped, while the rest upfolded over it before the slide definitely standed still (Figure $5 \mathrm{a}$ ). Of course, there are further possibilities - friction might decelerate the slide face as well (Figure $5 \mathrm{~b}$ ). An abrupt increase of the bottom inclination would lead to the similar result as the horizontal speed component of the rear slide part $\left(\mathbf{v}_{\mathbf{r}}\right)$ is larger than in the case of head $\left(\mathbf{v}_{\mathbf{h}}\right)-$ Figure $5^{c}$. The fold is the only example in horizontally layered surrounding rocks - no other was seen in a wider outskirt and nearby sandstone massifs are not accessible without a climbing equipment.

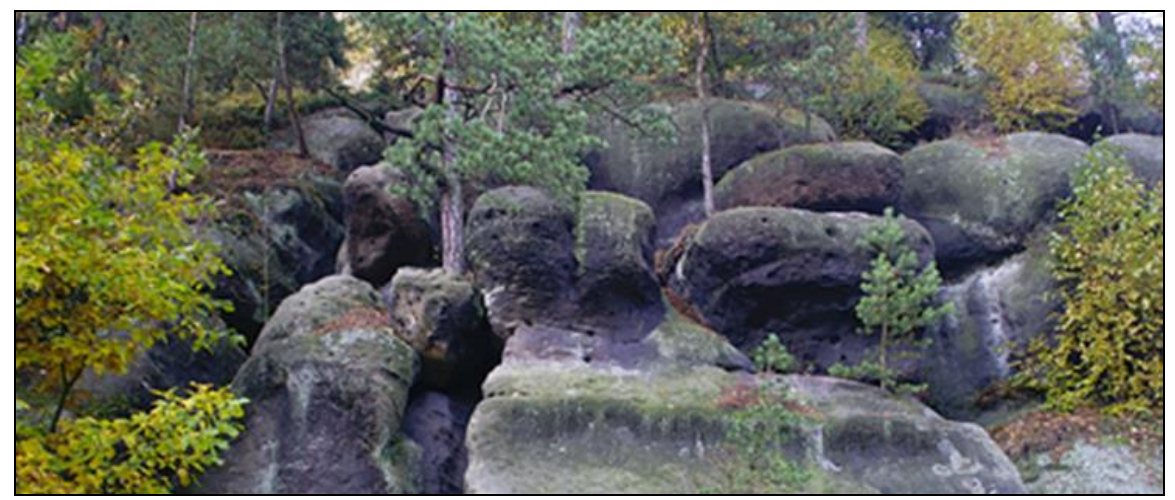

Figure 6. Loaf-like weathering of the Oybin mesa

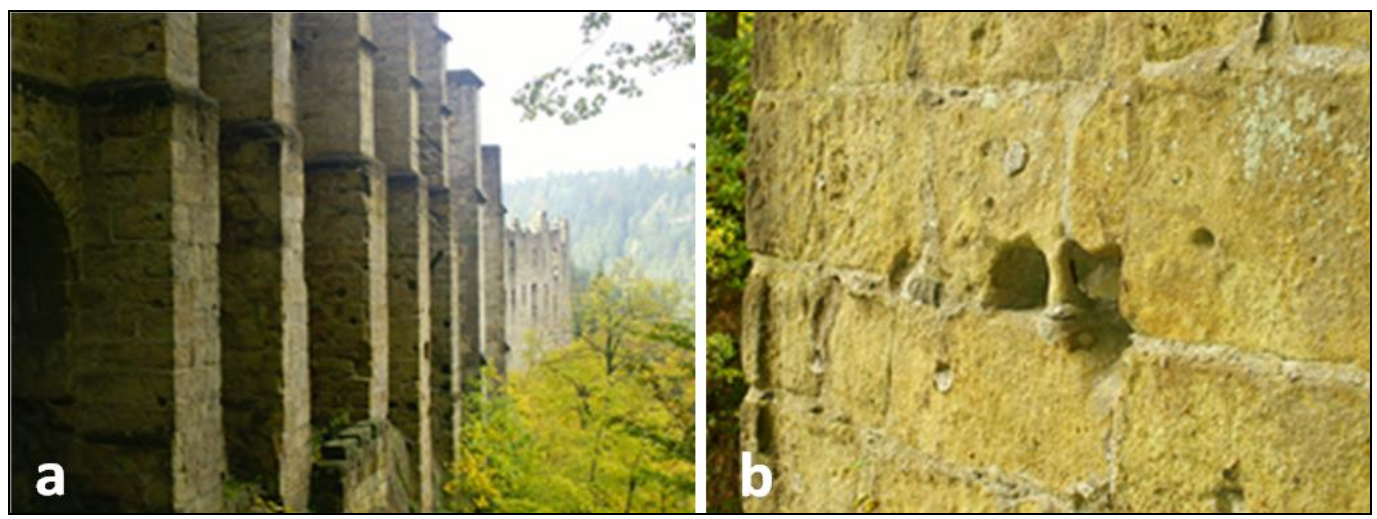

Figure $7 \mathbf{a}, \mathbf{b}$. Buttresses (a) and the pillar in one of blocks (b)

The mesa is also a good example of a specific form of weathering. Particular blocks of sandstones are eroded into the shape of loaves (Figure 6). These forms resemble the erosion in sandstones on the Czech side of frontier (Rynoltice); nevertheless, sandstones near Rynoltice are of a similar (Upper Cretaceous) age but their composition is somewhat different. At the mesa foot, there are huge eased blocks loosened from the massif. Besides these large forms, the mesa offers many finer examples of selective erosion. The northern wall of Oybin castle was built of sandstone blocks about $30 \mathrm{~cm}$ thick. These blocks were also used for transverse supporting buttresses, located in the castle northern wall (Figure $7 \mathrm{a})$. One of stones exhibits a phenomenon usual in nature but not in manmade structures 
- about 10 centimeters high pillar facing outwards (Figure $7 \mathrm{~b}$ ). Like the mentioned above fold, this feature is unique here. The question of its origin may be answered in two ways (Bryan \& Jones, 1997). A generally accepted principle of weathering in sandstones and origin of typical forms (crusts, honeycombs, ledges, cavities, pillars, etc.) is called suffosion or piping (Demek, 1987). This process does not represent karsting sensu stricto - water only dilutes the cement component in the rock. Loosened grains are then transported away. Contrary to the genuine karst, such a material does not form any new structures.

There is also another and very interesting explanation. Recently, geologists from the Charles University in Prague have performed experiments with so called locked sands (Bruthans et al., 2014), first mentioned at the end of 1970's (Dusseault \& Morgenstern, 1979). Particular grains are not cemented or they are cemented very slightly. But a permanent load of overlaying strata locks grains together and such a material looks like a firm rock, though very brittle. Experiments of Czech geologists (Bruthans et al., 2014) have demonstrated the following fact: if the superjacent strata burden their bedrock less (for example due to erosion), the subjacent rock becomes instable and grains get loose. This degradation proceed from outside towards the rock interior. But such a process decreases loaded horizontal cross-sections in the structure and further destruction is stopped because a residual superjacent load is able to lock remaining grains of underlying sands again. According to the authors (Bruthans et al., 2014), this process can lead to the origin of rock windows and portals, cavities, pillars and other bizarre forms. Nonetheless, in this particular case, suffosion is more probable. According to the visual inspection, the block in the buttress is really solitary and the load of overlying stones must be considerable. The effects of locked sands would have certainly been observed in higher structures as well.

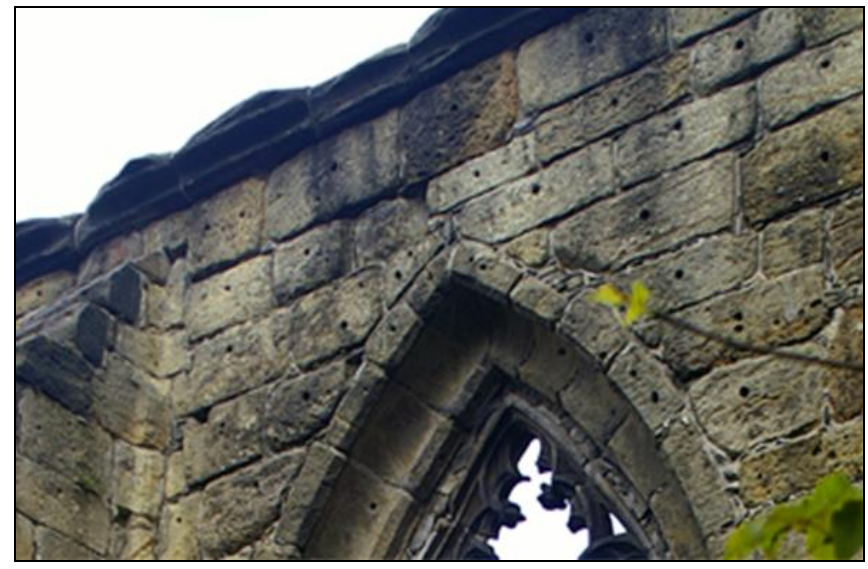

Figure 8. Handling dents for crampon jaws

In the opinion of this article authors, a possible scenario of the pillar origin may be as follows: Medieval masons used a cubic block of sandstone - blocks vary in their shapes and sizes. Two neighboring stones were cemented with mortar, however, not consistently. Precipitation water leaked into the joint and diluted the cement from inside, while joints between other blocks are full of mortar and stones are thus better protected. Exposed surfaces of surrounding blocks were slowly weathering (dimples, crusts), while water penetrating through the joint between the blocks gradually formed a cavity which finally proliferated onto the outer surface through two nearby holes (today divided by the pillar). Water drains via the nearer opening where it has formed a well visible groove. 
According to the date of conversion ordered by Charles IV, the whole process is not older than 650 years because medieval wallers would not use an improper block. The cavity between the stones still enlarges. On the other hand, there are numerous dents in blocks which are not of natural origin. Dents provided easy handling with blocks (masons used the so called crampons and made these pits intentionally (Šefců 2013 - Figure 8). Some of them are fitted with mortar, especially in lower parts of walls and buttresses.

In other accessible locations it is possible to find cyclically arranged sandstones and conglomerates; however the size of grains within particular cycles increases upwards. Such a texture is typical for the mentioned above progradation. During this stage of sedimentation, the sea was regressing towards NW and materials transported from the land were thus coarser. A new transgression at the beginning of another cycle brought a fast change - coarse sands and conglomerates were replaced with fine deep water sediments again (Wilmsen \& Niebuhr, 2014). This fact is well documented in Figure 9a. Selective weathering (Figure 9b) more affects coarser parts of each cycle: conglomerates, if directly exposed to precipitation, degrade faster than subjacent finer materials do. In conglomerates, the volume of dissolvable cement is higher so they are more liable to suffosion. On the top of the mesa, weathering left most obvious traces. Rocks are deeply eroded here - there are wide joints and clefts; suffosion also caused slacking ledges and irregular honeycombs in less stable coarse strata.

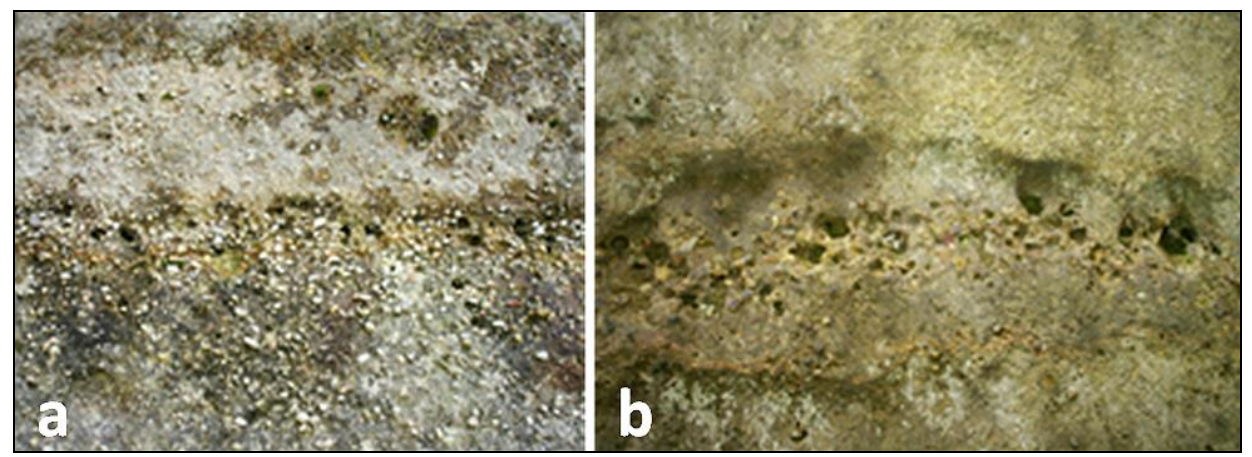

Figure 9 a, b. Progradation pattern (left) and selective erosion in coarse layers (right). Progradation is well visible at the main castle gate (Figure 1 - left); other forms of weathering are circled in the Figure 1 right part(the top of themesa) or indicated by arrows. Loaf like weathering is indicated rightmost there

\section{CONCLUSION}

The mesa of Oybin is a „textbook example“of processes which asserted in the course of sedimentation and weathering after the complex of sandstones was uplifted along the Lusatian fault. Folding within a later stage of lithification is indicated as well as later selective weathering. The role of suffosion - as the main form of erosion - is emphasized here. A unique rock pillar in one of sandstone construction blocks indicates how long such a phenomenon can be formed for. Oybin with its attractive surroundings represents a good choice for those who are interested in history and nature. The Zittau region does not belong among richest ones and tourism is one of the main sources of income for local people. Moreover, the Zittau Mountains have an advanced infrastructure; between Zittau and Oybin it is possible to travel on historical narrow gauge trains (perennial traffic) which serve as the suburban transportation here (Zittauer schmalspurbahn, official website). The location is well accessible from the Czech Republic as well via a good road from Jablonné. The authors thus assume that connecting historical landmarks with natural features could bring a better level of experience tourism in this part of Germany. 


\section{Acknowledgments}

Project of Specific University Research (SGS) no. SP2018/24

\section{REFERENCES}

Bruthans, J., Soukup, J., Vaculíková, J., Filippi, M., Schweigstillová, J., Mayo, A. L., Mašín, D., Kletetschka, G., \& Řihošek, J. (2014). Sandstone landforms shaped by negative feedback between stress and erosion. Nature Geoscience, Macmillan Publishers Limited, 7, 597 - 601. DOI: 10.1038/ngeo2209.

Bryan, R., \& B., Jones, J.A.A. (1997). The significance of soil piping processes: inventory and prospect. Geomorphology, 20, 209-218.

Burda, J. (2016). Rebilance zásob podzemních vod. Závěrečná zpráva, př́loha 2/39 (The rebalance of underground waters reserves, edit. final report, complement no. 2/39). ČGS, Praha.

Cajz, V. (2003). Současný stav poznatků o oherském riftu (The current status of knowledge on the Eger graben). Essentia, 2004, 33.

Cháb, J., Stráník, Z., \& Eliáš, M. (2007). Geologická mapa České republiky (The Czech Republic geological map) 1:500 000. CGS, Praha. ISBN 978-80-7075-666-9.

Chlupáč, I. (2002). Geologická minulost České republiky (The Czech Republic geological past). Academia, Praha. ISBN 978-80-200-0914-2.

Demek, J. (1987). Obecná geomorfologie (General geomorphology). Academia, Praha.

Dusseault, M.B., Morgenstern, N.R. (1979). Locked sands. Q. Jl Engng Geol., (12), 117 - 131. DOI: 10.1144 /GSL.QJEG.1979.012.02.05.

Fediuk, F., Losert, J., \& Röhlich, P. (1958). Geologické poměry území podél lužické poruchy ve šluknovském výběžku (Geol. situation of the area along the Lusatian fault in the Šluknov headland. Rozpr. Čs. Akad. Věd, 9, 1-42.

Koláček, L.Y. (2014). Kouzelným pomezím Lužických hor (Through the magical borderland of the Lusatian Mountains). Regia, Praha. ISBN 978-80-87866-05-4.

Lewis, K.B. (1971). Slumping on a continental slope inclined at $1-4^{\circ}$. Sedimentology, 1971, 16, 97-110.

Michalski, S., Götze, J., Siedel, H., Magnus, M., \& Heimann, R.B. (2002). Investigations into provenance and properties of ancient building sandstones of the Zittau/Görlitz region (Upper Lusatia, Eastern Saxony, Germany). Geological Society London Special Publications 205(1): 283-297. DOI: 10.1144/GSL.SP.205.01.21.

Ricketts, B. (2015). Atlas of sediments and sedimentary geology. Geological digressions. https://www.geological -digressions.com/atlas-of-sediments-and-sedimentary-structures.

Šefců, O. (2013). Architektura; lexikon architektonických prvků a stavebního řemesla (Architecture; lexicon of architectonic elements and construction craft). Grada Publ., Praha. ISBN 978-80-247-3120-9.

Svoboda, J. (1983). Encyklopedický slovník geologických věd (The Encyclopedic glossary of geological sciences). Academia, Praha.

Váně, M. (1999). Geologie Lounska pro třetí tisíciletí (Geology of the Louny area for the third millenium). Nákladem vlastním (At own expenses), Chomutov.

Voigt, T. (2017). Exkursionsführer Zittauer Gebirge. Saxon part (The excursion guide for the Zittau mountains, Saxon part). (2017). www.resibil.eu/downloads-4111.html, accessed 09.09.2018.

Wenger, E., Büchner, J., Tietz, O., \& Mrlina, J. (2017). The polycyclic Lausche Volcano (Lausitz Volcanic Field and its message concerning landscape evolution in the Lausitz Mountains (northern Bohemian Massif, Central Europe. Geomorphology, (292). DOI: 10.1016/j.geomorph.2017.04.021.

Wilmsen, M., \& Niebuhr, B. (2014). Die Kreide in Sachsen (The Saxon Cretaceous). Geologica Saxonica: Journal of Central European Geology [online]. Senckenberg, 60 (1), Dresden. http://www.senckenberg.de/files/content/ forschung/publikationen/geologicasaxonica/6o_1/o1_geologica-saxonica6o-1_2014_wilmsen_niebuhr.pdf.

Wilmsen, M., Niebuhr, B., Chellouche, P., \& Pürner, T. (2010). Facies pattern and sea-level dynamics of the early Late Cretaceous transgression: a case study from the lower Danubian Cretaceous Group (Bavaria, southern Germany). Facies, 56, 483-507, Erlangen.

*** https://www.google.cz/maps/place/Oybin,+Německo/@5o.8427183,14.7159628,13z/data=!3m1!4b1!4m5!3 m4!1sox47093dfoe467ae8b:0x421b1cb4288dd7o!8m2!3d50.836845!4d14.7457956, accessed 11.10.2018.

*** https://www.zittauer-schmalspurbahn.de, accessed 10.08.2018.

Submitted:

27.08.2018
Revised:

29.04.2019
Accepted and published online 21.05.2019 